\title{
An analysis of Taiwanese meat demand within domestic and imported upon entering into World Trade Organization (WTO)
}

\author{
Sheng-Ju Huang ${ }^{1 *}$ and Chiang-Ren Show ${ }^{2}$ \\ ${ }^{1}$ Department of Business Administration, Lung Hwa University of Science and Technology, Taoyuan, Taiwan or No. 300, \\ Sec.1, Wanshou Rd. Guishan, Taoyuan County 33306, Taiwan. \\ ${ }^{2}$ Department of Agricultural Economics, National Taiwan University, Taipei, Taiwan.
}

Accepted 15 June, 2011

\begin{abstract}
For the meat demand within domestic and imported upon entering into World Trade Organization (WTO) analysis, the almost ideal demand system (AIDS) model is utilized. The empirical results show that: domestic pork was the primary choice of Taiwanese $(50.14 \%)$ among the meat items; seasons have significant effect on meat consumption; Reaction of Taiwanese were sensitive for domestic pork, domestic fishery product and imported chicken. In addition, among all meat items, imported chicken, imported beef, domestic pork and domestic fishery products have the highest expenditure elastic ties, indicating that Taiwanese would increase their consumption of these meat items more than the others. Finally, the substitution effects significantly existed in the following meat items: domestic pork and imported pork, domestic chicken and domestic fishery product, imported beef and imported chicken; the complementary effects significantly existed in the following meat items: domestic chicken and imported pork, imported beef and imported pork. The complementary effects existed between domestic pork and that of the meat items of domestic fishery product, imported beef and imported chicken. The results of this study indicate that domestic and imported meat items is not totally substitutable. In order to reduce the impacts of imported meat items on domestic markets, self-ruling production control can be a way. Strategic marketing can also be applied to segment markets using domestic meat items with distinct qualitative attributes or different harvest seasons from imported meat items.
\end{abstract}

Key words:Meat, almost ideal demand system (AIDS) model, demand analysis

\section{INTRODUCTION}

Among the agricultural yields of Taiwan in 2009, crop production accounted for $43.92 \%$ of the gross agricultural output value, vegetables $11.68 \%$, flowers $3.01 \%$, livestock $34.88 \%$ and fish $21.10 \%$, fruit 16.145 . Livestock is the second output value in Taiwan agriculture. With regard to the output value of livestock products, pigs accounted for $16.18 \%$, chicken $9.07 \%$, eggs $4.90 \%$, beef

*Corresponding author. E-mail: f89627004@ntu.edu.tw. Tel: 886-2-82093211 ext 6519. Fax: 886-2-82093211ext6510.

Abbreviations: AIDS, Almost ideal demand system; WTO, world trade organization; SUR, seemingly unrelated regression; I3SLS, iterative three-stage least square; SAS, statistical analysis software.
$0.36 \%$, and mutton $0.21 \%$ (Agricultural Statistics Yearbook, 2009).

The import volume of livestock products was 220,000 ton in $2003,240,000$ ton in $2004,250,000$ ton in 2005 , 260,000 ton in $2006,210,000$ ton in $2007,250,000$ ton in 2008 , and 275,000 ton in 2009. The import value from 2003 - 2009 was USD420, USD460, USD560, USD554, USD527, USD667, and USD646 million, respectively (Monthly Bulletin of Agricultural Statistics, 2010). In recent years, the import volume has abruptly increased due to the deregulating policy on the importation of livestock products, entrails, and other important agricultural products. Along with the rapid growth of the economy and the sing level of income and standard of living, the domestic pattern of consumption also changes. The demand for traditional rice drops significantly, whereas that for meat, vegetables, and other sideline 
products increases. Meat is the main source of nutrients for the Taiwanese and accounts for the largest share in the Taiwanese's food expenditure. The annual consumption of meat per capita was $54.30 \mathrm{~kg}$ in 1985 and gradually increased to $73.72 \mathrm{~kg}$ in 2009 . The demand for pork was the highest, that is, $38.11 \mathrm{~kg}$, followed by other types of meat, namely, poultry, beef, and mutton at $30.28,4.19$, and $1.11 \mathrm{~kg}$, respectively (Food Supply and Utilization Yearbook, 2009). As such, meat plays an important role in the food consumption of the Taiwanese.

In January 2002, Taiwan joined the World Trade Organization (WTO). Their agreement stipulated that Taiwan must eliminate restrictions on import in "open market areas," remove non-customs obstacles, gradually reduce the tariff rate of agricultural products, and increase the import volume. Moreover, Taiwan should have an open market for belly and flank pork, chicken, animal entrails, and liquid milk beginning 2004 and allow the free import of all livestock products starting 2005, except for liquid milk and wet antler, because they were still subject to quota controls. The import volume of all types of meat, except for beef, has greatly increased after the initial period. Thereafter, free importation of all types of meat has been realized, but domestic meat has been neglected because of the increasing volume of importation at an economical retail price. In the long run, such importation of meat gradually would likely threaten the market of domestic agriculture. Therefore, an investigation of the substitution relationship between the domestic and the imported meat, especially the extent of influence on price, is necessary.

Among the studies on open meat markets, previous researchers have proposed countermeasures on the impact, future adjustment, and growth direction of particular meat sectors. However, these studies were limited only to the influence on the industry and on the supply and demand, rarely touching on the price substitution elasticity between domestic and imported meat products. The price substitution elasticity and the meat substitution relationship between domestic and imported meat products were never a concern of previous research. The industry is not only oblivious about the competitiveness of domestic meat, but the agricultural administration also lacks actual data to support its policy-making process. Most studies usually analyzed the meat demand of the Taiwanese only. Thus, this paper intends to conduct a systematic analysis of the demand of the Taiwanese for domestic and imported meat.

Meat demand can be analyzed using two methods: the demand for a single product and the systematic analysis of sector demand. Based on the Consumer Theory, the latter estimates the general meat demand system through the simultaneous equation system, aggregation, homogeneity, and symmetry in the economic theory and analyzes the substitution relationship between various types of meat (Heien, 1982). In the demand system literature, common methods include linear expenditure model (Klein and Rubin, 1947; Stone, 1954), Rotterdam model (Barten and Bettendorf, 1989), indirect translog model (Christensen et al., 1975), almost ideal demand system (AIDS) model (Deaton and Muellbauer, 1980), and Constant Elasticity Model (Huang and Haidacher, 1983).

The AIDS model has many advantages, one of which is that it can be derived from the Indirect Utility Function expressed by the price logarithm polynomial and expenditure. The model allows the total representatives of consumer demand to represent the overall market. It also provides the estimates of price commodity and cross and consumption elasticity, including the information related to agricultural administration. Although AIDS is a nonlinear model, it can use Stone's (1954) price index to solve other nonlinear issues and make the estimation easier. Thus, the AIDS model is adopted in this paper.

The monthly data of variables from the price and output volume of domestic meat and the price and weight of imported meat from 2002-2008 are used in this paper. The AIDS model (Deaton and Muellbauer, 1980) is used to estimate the substitution relationship between domestic and imported meat after Taiwan's accession to the WTO. This is to understand further the demand of the Taiwanese for meat products and to enable domestic producers and agricultural administrators to stipulate plans for industrial adjustment and development.

The paper is segmented as follow: First is the introduction, followed by a description of the theoretical model, that is, the AIDS model. An illustration of the data sources and the processing and estimation method is then given; followed by the empirical results, showing the demand parameters, and calculation of the elasticity, and finally, the conclusions.

\section{AIDS THEORETICAL MODEL}

The AIDS model is based on the following assumptions about domestic and imported meat. Specific commodities consumed are insufficiently evident, and can be divided into several items, the AIDS model includes theoretical economic assumptions about the aggregation, homogeneity, and symmetry of the demand system, and commodity consumption conforms to the principle of two-stage budgeting.

First, individual income is allotted to food, clothing, residence, transportation, children, entertainment, and so on. Second, meat belongs to the food category, thus the total budget for meat is divided into various types of meat that sums up the meat expenditure. Hence, meat demand is the secondary demand system below the total demand.

The AIDS model is based on the demand system model defined by Deaton and Muellbauer (1980). The expenditure function is the general linear algorithm with the independent price, as shown in Equation (1):

$\ln e(p, u) a(p)+u b(p)$

The AIDS model assumes that the expenditure function $e\left(\mathbf{p}^{-} u_{-}^{-}\right.$is

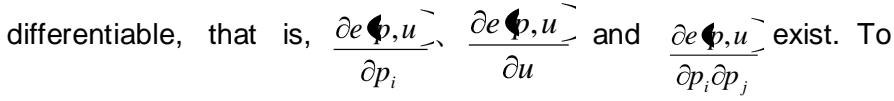


validate this estimation, the type of function $a \rho_{-}^{-}$and $b{ }_{-}^{-}$, as shown in Equations (2) and (3), must be defined.

$a$ ( $\alpha_{0}+\sum_{i=1}^{n} \alpha_{i} \ln p_{i}+\frac{1}{2} \sum_{i=1}^{n} \sum_{j=1}^{n} \gamma_{i j}^{*} \ln p_{i} p_{j}$

$b \bigotimes=\beta_{0} \prod p_{i}^{\beta_{i}}$

where $i, j=1,2, \ldots, n$ represents $\mathrm{n}$ types of commodities. Equations (2) and (3) are set in the expenditure function in Equation (1) to obtain Equation (4):

$\ln e \boldsymbol{Q}, u$ ₹ $\alpha_{0}+\sum_{i=1}^{n} \alpha_{i} \ln p_{i}+\frac{1}{2} \sum_{i=1}^{n} \sum_{j=1}^{n} \gamma_{i j}^{*} \ln p_{i} p_{j}+u \beta_{0} \Pi p_{i}^{\beta_{i}}$

Based on Shephard's Lemma theorem, the expenditure function for the first-order partial differentiation of the commodity price is used to obtain a commodity's compensated-demand function; $p_{j} / e(p, u)$ is multiplied on both sides to calculate the budget share of $\mathrm{i}^{\text {th }}$ commodity, as shown in Equation (5):

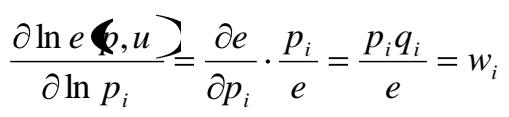

where $w_{i}$ is the budget share of commodity i. Partial differentiation of the expenditure function is conducted against $\ln p_{i}$ in Equation (4). Equation (4) can be expressed as the demand system indicated by the budget share, as shown in Equation (6):

$w_{i}=\alpha_{i}+\sum_{j=1}^{n} \gamma_{i j} p_{j}+\beta_{i} u \beta_{0} \prod p_{i}^{\beta_{i}}$

Parameter $\gamma_{i j}$ satisfies $\gamma_{i j}=\frac{1}{2} \boldsymbol{(}_{i j}^{*}+\gamma_{j i}^{*} \neq \gamma_{j i}$. When the rational consumer pursues utility maximization, the total income must be equal to the expenditure function. The utility function is expressed by the indirect utility function of price $(p)$ and expenditure $(\mathrm{m})$; that is, Equation (7) is obtained from Equation (4):

$$
\begin{aligned}
& u \beta_{0} \prod p_{i}^{\beta_{i}}=\ln e \varphi, u-\left[\alpha_{0}+\sum_{i=1}^{n} \alpha_{i} \ln p_{i}+\frac{1}{2} \sum_{i=1}^{n} \sum_{j=1}^{n} \gamma_{i j}^{*} \ln p_{i} p_{j}\right] \\
& \text { Equations (7) and (6) are derived to obtain Equation (8): } \\
& w_{i}=\alpha_{i}+\sum_{j=1}^{n} \gamma_{i j} \ln p_{j}+\beta_{i}\left[\ln e \varphi, u-\left(\alpha_{0}+\sum_{i=1}^{n} \alpha_{i} \ln p_{i}+\frac{1}{2} \sum_{i=1}^{n} \sum_{j=1}^{n} \gamma_{i j}^{*} \ln p_{i} \ln p_{j}\right)\right]
\end{aligned}
$$

Given that the parameters to estimate in Equation (8) are nonlinear, the price index proposed by Stone (1954) is used for substitution, i.e., $\ln P=\sum_{i=1}^{n} w_{i} \ln p_{i}$, to approach the linear demand system in empirical studies. The demand system expressed by the budget share in the AIDS model can be adapted to Equation (9):

$$
w_{i}=\alpha_{i}+\sum_{j=1}^{n} \gamma_{i j} \ln p_{j}+\beta_{i} \ln \left(\frac{m}{P}\right)
$$

where $i, j=1,2, \ldots, n$ represents $\mathrm{n}$ types of commodities; $p_{j}$ is the price of commodity $j ; w_{i}$ is the budget share of commodity $\mathrm{i} ; \mathrm{m}$ is the total expenditure; $\mathrm{P}$ is the Stone' Price Index and $\gamma_{i j}$ and $\beta_{i}$ are the coefficients to estimate.

Meat consumption is closely associated with output season and special occasions; this introduces the seasonal factor as the dummy variable. The intercept in Equation (9) (from January each each year as the base period) is expressed as follows:

$\alpha_{i}=\delta_{0}+\sum_{d} \delta_{i d} D_{d}$

where $D_{d}$ is the dummy variable of the month-specific seasonal factor; d represents the month-specific seasonal changes; and $\delta_{i d}$ is the additional influence of the month-specific seasonal factor on the budge share.

Equation (9) should be consistent with the general constraints of functions, including aggregation, homogeneity, and symmetry. year as the base period) is expressed as follows:

The constraints are as follows:

Aggregation: $\sum_{i=1}^{n} \gamma_{i j}=0 、 \sum_{i=1}^{n} \alpha_{i}=1 、 \sum_{i=1}^{n} \beta_{i}=0$

Homogeneity: $\sum_{j=1}^{n} \gamma_{i j}=0$

Symmetry: $\gamma_{i j}=\gamma_{j i}$

In empirical studies, data of the demand system are mainly based on time sequence. To avoid the first-order serial correlation and to understand the dynamic behavior of meat demand, this estimates it using the first-order differential (Jan, 2002; Li et al., 2005) and derives Equation (9) as follows:

$$
\Delta w_{i t}=\sum_{j=1}^{n} \gamma_{i j} \Delta\left(\ln p_{j}\right)_{t}+\beta_{i} \Delta\left[\ln \left(\frac{m}{p}\right)\right]_{t}
$$

In the equation, the first-order differential of Stone's price index can be divided to three items: 
Table 1. The budget share of domestic and imported meat in Taiwan.

\begin{tabular}{lcccccc}
\hline Meat Item & Domestic pork & Domestic chicken & Domestic fishery & Imported pork & Imported beef & Imported chicken \\
Budget share & 0.5014 & 0.1025 & 0.2820 & 0.0311 & 0.0529 & 0.0301 \\
\hline
\end{tabular}

$$
\Delta \log P_{t}^{*}=\sum_{i=1}^{n} w_{i t} \Delta \log p_{i t}+\sum_{i=1}^{n} \Delta w_{i t} \log p_{i t}-\sum_{i=1}^{n} \Delta w_{i t} \Delta \log p_{i t}
$$

Let us take time sequence as an example. The values of the two items are relatively small (Alston and Chalfant, 1993) and is often neglected in empirical studies (Xu and Veeman, 1996).

The demand elasticity of the AIDS model is the demand system function. Marshallian demand elasticity is estimated through the following three equations:

Price elasticity: $e_{i i}=\frac{\gamma_{i i}}{w_{i}}-\beta_{i}-1$

Cross elasticity: $e_{i j}=\frac{r_{i j}}{w_{i}}-\left(\beta_{i}\right)\left(\frac{w_{j}}{w_{i}}\right)$

Consumption elasticity: $e_{i m}=\left\{\frac{\beta_{i}}{w_{i}}\right\}+1$

where $e_{i i}$ is the price elasticity that measures the sensitivity of price change of $\mathrm{i}^{\text {th }}$ commodity triggering the change of demand; $e_{i j}$ is the cross price elasticity that measures the sensitivity of price change in other commodities triggering the demand change of $i^{\text {th }}$ commodity; and $e_{i j}$ is the consumption elasticity that measures the sensitivity of expenditure change triggering the demand change.

\section{DATA DESCRIPTION AND METHOD OF ESTIMATION}

\section{Definition of variables and data processing}

This paper aims to understand the meat demand within domestic and imported upon entering into WTO. The scope of the meat includes fresh, cold-stored, and frozen meat with a high percentage in the food structure for the final consumers. Other processed meats or entrails are not included; hence, meat choices include domestic pork, meat, and fish and imported beef, pork, and chicken. The sample estimation was from 2002-2008, a total of seven years of the month-specific data. Secondary data were taken from the statistics published by government agencies, including monthly and annual agricultural statistics, annual fishery statistics, and customs import/export, among others. Based on the budget share of meat, the Taiwanese choose domestic pork, accounting for $50.14 \%$ of the total meat expenditure, followed by domestic fish $(28.20 \%)$. Refer to Table 1 for the budget share of domestic and imported meat.

In the absence of data about the consumption of fish and livestock in Taiwan, this paper estimates the amount of domestic meat available for consumption from production to the actual consumption. Meat supply refers to the kind of animal production and is expressed in "numbers," whereas consumption in retail market is calculated by weight. Based on the annual report of the agricultural statistics, the average yield rate of each pig is $82.5 \%$, and the average weight is $110 \mathrm{~kg}$. After deducting the exported volume of pork, the amount of pork available for consumers is obtained. With regard to fish consumption, the amount of fish available for consumption is obtained by deducting the export volume of fish from the gross output. As to chicken consumption, the average weight of white Dorking in Taiwan is about $1.8 \mathrm{~kg}$ and that of Fangzai chicken is about $2.4 \mathrm{~kg}$, with a yield rate of about $80 \%$. The amount of chicken available for consumption is obtained by deducting the export volume (Unit: $\mathrm{kg}$ ). The consumable amount of imported meat is estimated from the import volume (Unit: $\mathrm{kg}$ ).

The price of retail meat is uncompetitive based on the consumer price index in 2002. The price of pork meat is based on the retail price of belly and flank meat, whereas that of fish is obtained by dividing the total value of fish products with the throughput. Domestic chicken includes Fangzai and Dorking, and the average price is obtained by acquiring the mean of the price and transaction volume. The retail price of imported meat is obtained by dividing the total value of imported meat at the customs with the import volume (regarded as the import equilibrium price from the export state to Taiwan port) plus the $35 \%{ }^{1}$ markup by retailers (unit: NTD/Kg).

\section{Method of estimation}

Given that meat output depends on seasonal changes, this paper integrates Equation (10) into Equation (9) to estimate the parameters to conform to the actual phenomenon and provide precise empirical results. The empirical regression equation is as follows:

$$
w_{i}=\delta_{0}+\sum_{d} \delta_{i d} D_{d}+\sum_{j} \gamma_{i j} \log p_{j}+\beta_{i} \log \left(\frac{m}{P}\right)
$$

As this paper assumes that the actual situation of domestic and imported meat conforms to aggregation, homogeneity, and symmetry implied by the AIDS model, Equations (11), (12), and (13) and other constraints are introduced to the model. The total budget share of meat is 1 , causing the singularity of covariance matrix during the estimation. One equation should be deleted to estimate the demand system; thus, we do not include the equation of imported pork. We assume that the random errors at different time points are independent from each other and that estimating the parameters by the maximum likelihood method and deleting any equation will not influence the result of the parameter estimation (Barten, 1969). The parameter estimation of the deleted equation can be answered by aggregation, homogeneity, symmetry, and other constraints.

The seemingly unrelated regression (SUR) method proposed by Zellner (1962) in economic metering is often used to establish simultaneous estimation formulas for the demand system. As regards the endogeneity issues of variables in the meat demand

Meat expenditure is obtained by multiplying the retail price of meat products with the monthly consumption per capita. 
system, LaFrance (1991) emphasized that the total meat expenditure is not fixed and must be handled properly. If the iterated SUR is used to estimate parameters, they will not have statistical consistency (Jan, 2002). Hence, this paper uses the iterative threestage least square (I3SLS) to estimate the parameters.

\section{EMPIRICAL RESULTS}

Along with the statistical analysis software (SAS) 9.1 and the month-specific data from 2002-2008 after Taiwan's accession to the WTO, the I3SLS is used to estimate the demand system of domestic and imported meat in Taiwan, illustrate the economic significance of the parameter estimation, and calculate the Marshallian demand elasticity.

Table 2 shows the parameter estimation in the AIDS model of domestic and imported meat in Taiwan. The estimation results indicate that the total expenditure coefficient of domestic pork and fish and imported beef and chicken are apparently positive. However, the total expenditure coefficients of domestic chicken and imported pork are significantly negative. If the Taiwanese spend more on meat, the budget share of domestic pork and fish and imported beef and chicken will increase, whereas that of domestic chicken and imported pork will decrease. The self-price coefficients of domestic pork and chicken and imported pork and beef are significantly positive, whereas those of domestic fish and imported chicken are significantly negative. Thus, when the price of domestic pork and chicken and imported pork and beef increase, the expenditure share of such meat also increases. In contrast, the expenditure share of domestic fish and imported chicken increases as the price decreases. Producers refer to such estimations when making the pricing strategy.

With respect to the month-specific seasonal changes, January of each year is taken as the benchmark. The estimation of seasonal parameters in Table 2 indicates that the expenditure share of domestic and imported meat is significantly correlated with the seasonal changes. The expenditure share of domestic pork in February is significantly higher in other months, possibly because of the lunar new year festival. The expenditure share of domestic pork in December is significantly lower than that in other months, but that of chicken is higher than that in other months possibly because people prefer chicken when replenishing nutrients. The expenditure share of domestic fish in May, November, and December is significantly higher than that in other months because these are the months when tuna and cuttlefish thrive. The expenditure share of imported pork in February and June is significantly lower than that in other months. The expenditure share of imported beef in June and July is higher than that in other months, and that in February is significantly lower than that in other months. The expenditure share of imported chicken in March and April is significantly higher than that in other months, and that in December is significantly lower than that in other months.

The results of the parameters estimation are presented in Table 2. As shown in Table 3, equations (16), (17), and (18) are used to calculate the Marshallian price elasticity, cross price elasticity, and consumption elasticity, respectively. Table 3 shows that the self-price elasticity of domestic pork, chicken, and fish and imported pork, beef, and chicken is significantly negative, which conforms to the condition of "negative" demand law in the economic theory. The self-price elasticity of domestic pork and fish and imported chicken is greater than 1 , indicating high elasticity and considerable influence of price on the consumption volume, such that when the price of domestic pork and fish and imported chicken increases, the consumption decreases, and vice versa. The self-price elasticity of domestic chicken and imported pork and beef is less than 1 , indicating the lack of elasticity and that the consumption will not be easily influenced by price. Hence, the number of consumers decreases as the price of domestic pork and fish and imported chicken increases, whereas the demand for meat increases considerably when price decreases.

With regard to consumption elasticity, all meat products are significantly positive, indicating that meat is considered normal goods to the Taiwanese. Meat consumption is likely to increase along with the total meat expenditure. The Taiwanese's consumption elasticity of domestic pork and fish, imported beef and chicken is greater than 1, indicating their slight flexibility. When the total meat expenditure increases, the demand for domestic pork and fish and imported beef and chicken also increases. Thus, the importance of domestic meat, such as pork and fish, is emphasized. With regard to imported meat, beef can satisfy the market demand on high-protein food. The importation of particular chicken parts can also satisfy the preference of the Taiwanese. Hence, when the total meat expenditure increases, the consumption of domestic pork and fish and imported beef and chicken also increases.

Based on the Marshall cross price elasticity, if the cross elasticity is positive, two types of meat can be substitutable; if negative, they are complementary. If the result of elasticity estimation is not significant, the substitutable or complementary relationship may not be apparent. Based on Table 3, the cross elasticity between meat is either negative or positive and asymmetric. This paper illustrates the rule on meat with regard to the substitutable or complementary relationship. Domestic and imported meat can be substituted, indicating that when the price of domestic pork rises, the Taiwanese will resort to imported pork. Domestic pork and fish are complementary due to the difference in taste. Domestic pork and imported beef are complementary possibly because imported beef has high quality and can meet the market demand for high-protein food than the different market segments of domestic pork. Domestic chicken and fish can be substituted because both are white meat. Imported beef and pork are complementary possibly because 
Table 2. AIDS parameter estimates of meats within domestic and imported in Taiwan.

\begin{tabular}{|c|c|c|c|c|c|c|}
\hline & $\begin{array}{c}\text { Domestic } \\
\text { pork }\end{array}$ & $\begin{array}{l}\text { Domestic } \\
\text { chicken }\end{array}$ & $\begin{array}{c}\text { Domestic } \\
\text { fishery }\end{array}$ & $\begin{array}{c}\text { Imported } \\
\text { pork }\end{array}$ & $\begin{array}{c}\text { Imported } \\
\text { beef }\end{array}$ & $\begin{array}{l}\text { Imported } \\
\text { chicken }\end{array}$ \\
\hline Expenditure & $\begin{array}{c}0.0129^{* * *} \\
(41.57)\end{array}$ & $\begin{array}{c}-0.0017^{\star} \\
(-1.92)\end{array}$ & $\begin{array}{c}0.0040^{* \star *} \\
(3.64)\end{array}$ & $\begin{array}{c}-0.0302^{* \star \star} \\
(-6.78)\end{array}$ & $\begin{array}{c}0.0067^{* \star *} \\
(4.17)\end{array}$ & $\begin{array}{c}0.0082^{*} \\
(1.78)\end{array}$ \\
\hline Domestic pork & $\begin{array}{c}0.0025^{\star \star *} \\
(11.72)\end{array}$ & $\begin{array}{c}-0.0005 \\
(-1.5)\end{array}$ & $\begin{array}{c}-0.0016^{* * *} \\
(-7.03)\end{array}$ & $\begin{array}{c}0.0008^{\star \star \star} \\
(3.36)\end{array}$ & $\begin{array}{c}-0.0091^{* * *} \\
(-2.95)\end{array}$ & $\begin{array}{c}-0.0003 \text { ** } \\
(-2.64)\end{array}$ \\
\hline $\begin{array}{l}\text { Domestic } \\
\text { chicken }\end{array}$ & $\begin{array}{c}-0.0005 \\
(-1.5)\end{array}$ & $\begin{array}{c}0.0013^{*} \\
(1.76)\end{array}$ & $\begin{array}{c}0.0042^{* * *} \\
(5.04)\end{array}$ & $\begin{array}{c}-0.0054^{* * *} \\
(-5.78)\end{array}$ & $\begin{array}{l}0.0002 \\
(0.13)\end{array}$ & $\begin{array}{c}0.0002 \\
(0.47)\end{array}$ \\
\hline Domestic fishery & $\begin{array}{c}-0.0016^{* * *} \\
(-7.03)\end{array}$ & $\begin{array}{c}0.0042^{* * *} \\
(5.04)\end{array}$ & $\begin{array}{c}-0.0017^{*} \\
(-1.81)\end{array}$ & $\begin{array}{c}-0.0014 \\
(-1.62)\end{array}$ & $\begin{array}{l}0.0002 \\
(0.16)\end{array}$ & $\begin{array}{c}0.0003 \\
(0.77)\end{array}$ \\
\hline Imported pork & $\begin{array}{c}0.0008^{\star * *} \\
(3.36)\end{array}$ & $\begin{array}{c}-0.0054^{\star \star *} \\
(-5.78)\end{array}$ & $\begin{array}{c}-0.0014 \\
(-1.62)\end{array}$ & $\begin{array}{c}0.0070^{* * *} \\
(3.04)\end{array}$ & $\begin{array}{c}-0.0044^{* * *} \\
(-3.13)\end{array}$ & $\begin{array}{c}0.0033^{*} \\
(1.77)\end{array}$ \\
\hline Imported beef & $\begin{array}{c}-0.0009^{* * *} \\
(-2.95)\end{array}$ & $\begin{array}{l}0.0002 \\
(0.13)\end{array}$ & $\begin{array}{l}0.0002 \\
(0.16)\end{array}$ & $\begin{array}{c}-0.0044^{* \star *} \\
(-3.13)\end{array}$ & $\begin{array}{c}0.0036^{*} \\
(1.73)\end{array}$ & $\begin{array}{c}0.0014^{* *} \\
(2.01)\end{array}$ \\
\hline Imported chicken & $\begin{array}{c}-0.0003^{* *} \\
(-2.64)\end{array}$ & $\begin{array}{l}0.0002 \\
(0.47)\end{array}$ & $\begin{array}{l}0.0003 \\
(0.77)\end{array}$ & $\begin{array}{c}0.0033^{*} \\
(1.77)\end{array}$ & $\begin{array}{c}0.0014^{* *} \\
(2.01)\end{array}$ & $\begin{array}{c}-0.0049^{* *} \\
(-2.51)\end{array}$ \\
\hline$\delta_{0}$ & $\begin{array}{c}-0.0107^{* * *} \\
(-17.73)\end{array}$ & $\begin{array}{c}-0.0108^{\star \star *} \\
(-5.50)\end{array}$ & $\begin{array}{c}-0.0029 \\
(-1.46)\end{array}$ & $\begin{array}{c}0.0337^{* * *} \\
(4.17)\end{array}$ & $\begin{array}{c}-0.0278^{* * *} \\
(-8.81)\end{array}$ & $\begin{array}{c}-0.0347^{\star * \star} \\
(-4.25)\end{array}$ \\
\hline D1 & $\begin{array}{c}0.0008^{* * *} \\
(3.98)\end{array}$ & $\begin{array}{c}-0.0038^{* * *} \\
(-6.41)\end{array}$ & $\begin{array}{c}-0.0014^{* *} \\
(-2.25)\end{array}$ & $\begin{array}{c}-0.0085^{\star *} \\
(-2.33)\end{array}$ & $\begin{array}{c}-0.0017^{*} \\
(-1.78)\end{array}$ & $\begin{array}{c}-0.0010 \\
(-0.31)\end{array}$ \\
\hline D2 & $\begin{array}{l}-0.0001 \\
(-0.56)\end{array}$ & $\begin{array}{c}-0.0020^{\star \star *} \\
(-3.94)\end{array}$ & $\begin{array}{c}-0.00004 \\
(-0.07)\end{array}$ & $\begin{array}{l}0.0009 \\
(0.26)\end{array}$ & $\begin{array}{c}0.0022^{* *} \\
(2.53)\end{array}$ & $\begin{array}{c}0.0058^{*} \\
(1.88)\end{array}$ \\
\hline D3 & $\begin{array}{c}0.0001 \\
(0.67)\end{array}$ & $\begin{array}{c}-0.0032^{* * *} \\
(-6.04)\end{array}$ & $\begin{array}{c}-0.0004 \\
(-0.69)\end{array}$ & $\begin{array}{c}-0.0020 \\
(-0.57)\end{array}$ & $\begin{array}{c}0.0022^{* *} \\
(2.45)\end{array}$ & $\begin{array}{c}0.0068^{* *} \\
(2.15)\end{array}$ \\
\hline D4 & $\begin{array}{c}-0.0007^{* * *} \\
(-3.93)\end{array}$ & $\begin{array}{c}-0.0031^{* * *} \\
(-6.14)\end{array}$ & $\begin{array}{c}0.0028^{* * *} \\
(5.01)\end{array}$ & $\begin{array}{l}-0.0003 \\
(-0.08)\end{array}$ & $\begin{array}{c}0.0024^{* * *} \\
(2.79)\end{array}$ & $\begin{array}{l}0.0040 \\
(1.30)\end{array}$ \\
\hline D5 & $\begin{array}{l}0.0001 \\
(0.29)\end{array}$ & $\begin{array}{c}-0.0037^{* * *} \\
(-6.78)\end{array}$ & $\begin{array}{l}0.0002 \\
(0.41)\end{array}$ & $\begin{array}{c}-0.0060 \text { * } \\
(-1.68)\end{array}$ & $\begin{array}{c}0.0030^{* * *} \\
(3.25)\end{array}$ & $\begin{array}{l}0.0025 \\
(0.78)\end{array}$ \\
\hline D6 & $\begin{array}{l}-0.0002 \\
(-0.86)\end{array}$ & $\begin{array}{c}-0.0029 \text { *** } \\
(-5.42)\end{array}$ & $\begin{array}{l}0.0008 \\
(1.36)\end{array}$ & $\begin{array}{c}-0.0018 \\
(-0.52)\end{array}$ & $\begin{array}{c}0.0029 \text { *** } \\
(3.22)\end{array}$ & $\begin{array}{l}0.0003 \\
(0.08)\end{array}$ \\
\hline D7 & $\begin{array}{c}-0.0002 \\
(-1.01)\end{array}$ & $\begin{array}{c}-0.0011^{* *} \\
(-2.01)\end{array}$ & $\begin{array}{l}0.0009 \\
(1.55)\end{array}$ & $\begin{array}{c}-0.0017 \\
(-0.49)\end{array}$ & $\begin{array}{c}0.0015^{\star} \\
(1.69)\end{array}$ & $\begin{array}{l}-0.0033 \\
(-1.04)\end{array}$ \\
\hline D8 & $\begin{array}{l}-0.0001 \\
(-0.48)\end{array}$ & $\begin{array}{c}-0.0021^{* * *} \\
(-3.58)\end{array}$ & $\begin{array}{l}0.0007 \\
(1.12)\end{array}$ & $\begin{array}{l}-0.0026 \\
(-0.74)\end{array}$ & $\begin{array}{l}0.0012 \\
(1.22)\end{array}$ & $\begin{array}{l}-0.0029 \\
(-0.90)\end{array}$ \\
\hline D9 & $\begin{array}{l}-0.0001 \\
(-0.32)\end{array}$ & $\begin{array}{c}-0.0011 \text { * } \\
(-1.95)\end{array}$ & $\begin{array}{l}0.0007 \\
(1.19)\end{array}$ & $\begin{array}{c}-0.0004 \\
(-0.13)\end{array}$ & $\begin{array}{c}-0.0002 \\
(-0.27)\end{array}$ & $\begin{array}{c}-0.0033 \\
(-1.04)\end{array}$ \\
\hline
\end{tabular}


Table 2. Contd.

\begin{tabular}{|c|c|c|c|c|c|c|}
\hline D10 & $\begin{array}{c}-0.0001 \\
(-0.36)\end{array}$ & $\begin{array}{c}-0.0009^{*} \\
(-1.67)\end{array}$ & $\begin{array}{c}0.0012 \text { * } \\
(1.96)\end{array}$ & $\begin{array}{c}-0.0035 \\
(-1.00)\end{array}$ & $\begin{array}{c}-0.0014 \\
(-1.47)\end{array}$ & $\begin{array}{c}-0.0040 \\
(-1.27)\end{array}$ \\
\hline D11 & $\begin{array}{c}-0.0014^{* * *} \\
(-7.10)\end{array}$ & $\begin{array}{c}0.0011 \text { * } \\
(1.76)\end{array}$ & $\begin{array}{c}0.0059^{* * *} \\
(8.53)\end{array}$ & $\begin{array}{c}0.0010 \\
(0.28)\end{array}$ & $\begin{array}{l}-0.0015 \\
(-1.55)\end{array}$ & $\begin{array}{c}-0.0082^{* * *} \\
(-2.66)\end{array}$ \\
\hline$R^{2}$ & 96.83 & 82.99 & 89.02 & - & 81.16 & 78.65 \\
\hline D-W & 1.8969 & 1.7378 & 1.8890 & - & 1.7763 & 1.5206 \\
\hline
\end{tabular}

$\delta_{0}$, Constant term coefficient after adding the virtual variable into the model; T value, indicated in the bracket. *, ${ }^{* *}$, and ${ }^{* * *}$ represent when the level of significance is at $10 \%, 5 \%$, and $1 \%$, respectively. The estimated parameter is significantly different from 0 ; During empirical estimation, the equation of imported pork is initially deleted. The coefficient is given by the aggregation and homogeneity constraints of the model. $R^{2}$ and $D$-W cannot be obtained.

Table 3. Elasticity estimates of meat within domestic and imported in Taiwan.

\begin{tabular}{|c|c|c|c|c|c|c|c|}
\hline \multirow[b]{2}{*}{ Meat item } & \multicolumn{6}{|c|}{ Price elasticity } & \multirow[b]{2}{*}{ Expenditure } \\
\hline & $\begin{array}{c}\text { Domestic } \\
\text { pork }\end{array}$ & $\begin{array}{c}\text { Domestic } \\
\text { chicken }\end{array}$ & $\begin{array}{c}\text { Domestic } \\
\text { fishery }\end{array}$ & $\begin{array}{c}\text { Imported } \\
\text { pork }\end{array}$ & $\begin{array}{c}\text { Imported } \\
\text { beef }\end{array}$ & $\begin{array}{c}\text { Imported } \\
\text { chicken }\end{array}$ & \\
\hline Domestic pork & -1.0078 & -0.0036 & -0.0105 & 0.0009 & -0.0032 & -0.0014 & 1.0257 \\
\hline Domestic chicken & 0.007766 & -0.9861 & 0.0454 & -0.0518 & 0.0028 & 0.0025 & 0.9838 \\
\hline Domestic fishery & -0.0130 & 0.0134 & -1.0099 & -0.0053 & -0.0002 & 0.0008 & 1.0142 \\
\hline Imported pork & 0.5134 & -0.0729 & 0.2294 & -0.7444 & -0.0894 & 0.1346 & 0.0295 \\
\hline Imported beef & -0.0810 & -0.0092 & -0.0326 & -0.0867 & -0.9395 & 0.0220 & 1.1270 \\
\hline Imported chicken & -0.1480 & -0.0213 & -0.0657 & 0.1003 & 0.0309 & -1.1695 & 1.2733 \\
\hline
\end{tabular}

imported meat products have unique flavors and do not have apparent substitution relationships. Domestic and imported pork are complementary. Similarly, domestic chicken and imported pork are complementary possibly because particular parts of chicken are preferred by the Taiwanese.

The demand for domestic meat does not have apparent substitutable effect, whereas imported beef and chicken can be substituted.

\section{Conclusion}

This paper aims to understand the meat demand within domestic and imported upon entering into WTO. Using the AIDS model for analysis, fresh, cold-stored and frozen meat with a high ratio in the food structure, excluding other processed meat or entrails, consumed by the Taiwanese are classified into domestic pork, domestic chicken, domestic fish, imported beef, imported pork, and imported chicken. According to the results, the Taiwanese mainly choose domestic pork, accounting for $50.14 \%$ of total meat expenditure. The expenditure of domestic and imported meat is significantly related to seasonal changes. When other conditions are maintained, the total meat expenditure of the Taiwanese changes in the same way as consumption; that is, when the meat expenditure of the Taiwanese increases, meat consumption also increases. The consumption elasticity of domestic pork and fish and imported beef and chicken is greater than 1, indicating that when the total expenditure of meat increases, the demand for domestic pork and fish and imported beef and chicken also increases.

The self-price elasticity of domestic pork and fish and imported meat is greater than 1 , indicating high elasticity and that the consumption is easily influenced by price. That is, when the price of domestic pork and fish and imported chicken increases, the consumption decreases; whereas if the price decreases, the consumption greatly increases. In contrast, the self-price elasticity of domestic chicken and imported pork and beef is smaller than 1 , indicating the lack of elasticity and that consumer are not easily influenced by price. This result can serve as reference for producers when making a pricing strategy.

With regard to the substitutable or complementary relationship between meat products, domestic and imported pork are substitutable, indicating that when the price of domestic pork increases, the Taiwanese will likely turn to imported pork. Domestic pork and fish are complementary because of their difference in taste. Domestic pork and imported beef are also complementary 
possibly because of the latter's high quality and ability to meet the market demand for high protein food. Due to their different market sectors, domestic chicken and fish are substitutable. Both are also white meat, but do not have an apparent substitution relationship. Imported beef and pork are complementary, possibly because imported meat has a distinctive flavor and cannot have an apparent substitution relationship. Domestic pork and imported chicken, as well as domestic chicken and imported pork, are complementary possibly because particular chicken parts are preferred by the Taiwanese. Imported beef and chicken are comple-mentary. The demand for domestic meat does not lead to an evident substitution effect.

In 2002, Taiwan became a WTO member. The importation of all meat types has grown rapidly since 2005 when free importation was allowed, except for beef because its importation had already been enforced as early as 1967 . Based on results of this paper, the Taiwanese mainly choose domestic meat and that domestic and imported meat is not entirely substitutable. Hence, imported meat cannot substitute domestic meat, indicating that the Taiwanese have great demand for domestic meat and that the domestic meat market can still grow further. To reduce the influence of imported meat, aside from the self-control on output, domestic producers should choose suitable marketing strategies to avoid the importation period of substitutable meat and build market segment using products with different qualities.

\section{REFERENCES}

Alston JM, Chalfant JA (1993). The Silence of the Lambdas: A Test of the Almost Ideal and Rotterdam Models. Am. J. Agric. Econ., 75(2): 304-313.
Barten A (1969). Maximun Likelihood Estimation of a Complete System of Demand Equations. Euro. Econ. Rev., 1: 7-73.

Barten AP, Bettendorf LJ (1989). Price Formation of Fish: An Application of an Inverse Demand System. Euro. Econ. Rev., 33(8): 1509-1525.

Christensen LR, Jorgenson DW, Lau LJ (1975). Transcendental Lorgarithmic Utility Functions. Am. Econ. Rev., 65(3): 367-383.

Deaton A, Muellbauer J (1980). An Almost Ideal Demand System. Am. Econ. Rev., 70(3): 312-326.

Heien DM (1982). The structure of food demand: Interrelatedness and duality. Am. J. Agric. Econ., 64(1): 213-221.

Huang KS, Haidacher RC (1983). Estimation of a Composite Food Demand System for the United States. J. Bus. Econ. Statis., 1(4): 285-291.

Jan MS (2002). The Structural Change of Demand for Meat in Taiwan. Taiwanese Agric. Econ. Rev., 8(1): 75-105.

Klein LR, Rubin H (1947). A Constant Utility Index of the Cost of Living. Rev. Econ. Stud., 15(2): 84-87.

LaFrance JT (1991). When Is Expenditure 'Exogenous' in Separable Demand Model? West J. Agric. Econ., 16(2): 49-62.

Li G, Song H, Witt S (2005). Recent developments in econometric modeling and forecasting. J. Trav. Res., 44(1): 82-99.

Stone JRN (1954). Linear Expenditure System and Demand Analysis: An Application to Pattern of British Demand. Econometrica, 64(255): 511-527.

Xu X, Veeman M (1996). Model Choice and Structural Specification for Canadian Meat Consumption. Eur. Rev. Agric. Econ., 23(3): 301-315.

Zellner A (1962). An Efficient Method of Estimating Seemingly Unrelated Regressions and Tests for Aggregation Bias. J. Am. Stat. Assoc., 57(298): 348-368. 